\title{
ESTIMATING FINE DEAD FUEL MOISTURE CONTENT UNDER EQUATORIAL CLIMATE CONDITIONS
}

\author{
Benjamin Leonardo Alves White ${ }^{1 *}$, Maria Flaviane Almeida Silva ${ }^{2}$ \\ 1* Instituto Federal de Educação, Ciência e Tecnologia Baiano, Campus Xique-Xique, Bahia, Brasil - e-mail: benjmk@hotmail.com \\ ${ }^{2}$ Universidade Federal de Sergipe, Núcleo de Graduação em Medicina Veterinária, Nossa Senhora da Glória, Sergipe, Brasil - e-mail: \\ flavianesilvaufs@gmail.com
}

Received for publication: 22/03/2020 - Accepted for publication: 14/05/2020

\begin{abstract}
Resumo
Estimando o teor de umidade do material combustível fino e morto em condições de clima equatorial. A determinação do teor de umidade do material morto e fino (TUMMF) é importante para ações de prevenção e combate aos incêndios florestais, já que possui grande influência na ignição e no comportamento do fogo. O Fine Fuel Moisture Code (FFMC) do Fire Weather Index (FWI), consiste em um dos modelos mais utilizado no mundo para estimar o TUMMF. No entanto, trabalhos que avaliem a eficiência desse modelo no Brasil ou em regiões de baixa latitude são raros. O presente estudo teve por objetivo avaliar a eficiência do FFMC em uma área de clima equatorial e desenvolver um novo modelo capaz de estimar o TUMMF com maior precisão. Para tal, 861 amostragens aleatórias do TUMMF foram determinadas através da secagem em estufa. Os valores obtidos foram comparados com os estimados pelo FFMC e correlacionados com parâmetros meteorológicos para se construir um modelo de regressão. Os resultados obtidos apontam que o TUMMF foi superestimado pelo FFMC. As variáveis independentes com maior influência no TUMMF foram, em ordem decrescente de significância: umidade relativa do ar, temperatura do ar, quantidade de precipitação pluviométrica nas últimas 24 horas e número de dias sem chuva. $\mathrm{O}$ modelo desenvolvido apresentou bons parâmetros estatísticos $\left(\mathrm{r}^{2}=0.86\right.$; $\mathrm{p}<0.0001$; RMSE $=0.22$ ) e pode ser utilizado, em locais similares às áreas avaliadas neste estudo, para se estimar o risco diário de ocorrência de incêndios e para determinar as condições ideais para queimadas prescritas.
\end{abstract}

Palavras-chave: risco de fogo, climatologia dos incêndios, modelagem da umidade.

\section{Abstract}

The measurement of the fine dead fuel moisture content (FDFMC) is extremely important for forest fire prevention and suppression activities, as it has a great influence on the ignition probability and fire behavior. The Fine Fuel Moisture Code (FFMC) from the Fire Weather Index (FWI), is one of the most used models to estimate the FDFMC. Nevertheless, studies that assess the efficiency of this model in Brazil or in low latitude regions are rare. The present study aimed to evaluate the efficiency of the FFMC in an equatorial climate area and to develop a new model capable of estimating the FDFMC with greater precision. For this purpose, 861 random samples of fine dead fuel had their moisture content determined through oven drying. The obtained values were compared with those estimated by the FFMC and correlated with meteorological parameters to build a regression model. The results obtained show that the FDFMC was overestimated by the FFMC. The independent variables with the greatest influence on the FDFMC were, in decreasing order of significance: air relative humidity, air temperature, amount of rainfall in the last 24 hours and number of days without rainfall. The developed model presented good statistical parameters $\left(r^{2}=0.86 ; p<0.0001\right.$; RMSE $\left.=0.22\right)$ and can be used, in areas with similar characteristics of the study area, to estimate the daily fire risk and to determine ideal conditions for prescribed burns.

Keywords: fire risk, fire weather, fuel moisture modelling.

\section{INTRODUCTION}

The fuel moisture content (FMC) represents the amount of water present in the plant biomass expressed as a percentage of its dry fuel weight. The higher the FMC, the greater the difficulty for the fuel to burn, since a high amount of energy will be necessary to evaporate all the water and then initiate the combustion process (NELSON, 1984; MATTHEWS, 2014; WHITE, 2018).

While the moisture content of live fuels depends mainly on the physiological characteristics of the plants, the moisture content of dead fuels is affected by their size and by local atmospheric conditions, such as air temperature, relative air humidity, wind speed, solar radiation and rainfall (MATTHEWS, 2014). In the absence of rainfall, the dead FMC will depend only on the exchange of water vapor between the fuel and the environment (adsorption and desorption). In a situation when the air temperature and humidity remain constant, the dead fuel tends to reach the equilibrium moisture content, where there is no net exchange of moisture between environment and fuel (NELSON, 1984). According to the same author, this condition can only be achieved in experiments carried out in a laboratory under controlled climate conditions, since in nature, the temperature and the air relative humidity vary continuously throughout the day.

FLORESTA, Curitiba, PR, v. 51, n. 3, p. 696-702, jul/set 2021

White, B. L. A. et.al. 
The fine dead fuel is represented by the one hour timelag fuel class (timelag refer to the amount of time it takes a dead fuel particle to reach about $63 \%$ of the difference between its current moisture content and the equilibrium moisture content). This includes dead needles, leaves, herbaceous plants and fine stems generally found in the litter layer with diameter less than $1 / 4 "(0.64 \mathrm{~cm})$. The moisture content of these fuels can change rapidly with rainfall or other changes in atmospheric conditions. Fuel with a larger diameter (10-h, 100-h and 1000-h timelag fuels), on the other hand, generally respond more slowly to changes in environmental conditions. The greater the fuel diameter the slower the moisture content will change (MATTHEWS, 2014).

The moisture content of the dead fine fuel load (1-h timelag) is recognized as a key parameter that influences the fire ignition and behavior (GISBORNE, 1928; WHITE, 2018). The real-time knowledge of the fine dead fuel moisture content (FDFMC) is essential to determine how the fire will behave: rate of spread, flame length, fire line intensity and other characteristics, since wildfires usually begin and propagate in the fine dead fuel load that composes the forest litter (WHITE, 2018). Gisborne (1928) initially proposed that the inflammability of the forest duff is directly related to the moisture content of the fine dead fuels that form the forest floor (Table 1). Since then, the fine fuel moisture content has been used to assess wildfire risk. Therefore, efficient preventive actions, such as prescribed burns and firefighting activities will more likely be successful if the FDFMC is known.

Table 1. Inflammability of the forest duff according its moisture content.

Tabela 1. Inflamabilidade da liteira florestal de acordo com seu teor de umidade

\begin{tabular}{ll}
\multicolumn{1}{c}{ Moisture content (\%) } & \multicolumn{1}{c}{ Inflammability } \\
\hline More than 25 & None \\
19 to 25 & Very low \\
14 to 18 & Low (camp fires become dangerous) \\
11 to 13 & Medium (matches become dangerous) \\
8 to 10 & High (matches always dangerous) \\
2 to 7 & Extreme (all sources of ignition dangerous) \\
\hline
\end{tabular}

*Fonte: Gisborne (1928).

*Font: Gisborne (1928).

Despite the relationship between weather and dead fuel moisture content has been studied for over a century, reliable methods to predict the variation of the FMC have not yet been developed (WHITE, 2018). Various approaches and models were developed over the years, however, they usually have restricted application, being unable to predict with efficiency in situations where the climate and the vegetation characteristics are different from the environments where they were developed (WHITE, 2018). Among several existing models currently in use to estimate the FDFMC and, consequently, the wildfire risk, the Canadian Forest Weather Index (FWI) (VAN WAGNER, 1974) stands out, since it is the most used on the planet (BIANCHI; DEFOSSE, 2014; WHITE, 2018). The Fine Fuel Moisture Code (FFMC) is a component of the FWI and is calculated based on meteorological parameters (air temperature and relative humidity, wind speed and rainfall) measured at noon (VAN WAGNER, 1974). According to White (2018) the calculation of the FFMC is complex and based on 13 different equations, which may complicate its applicability.

This study has the objective to assess the efficiency of the FWI - FFMC in determining the FDFMC and, based on the obtained results, to develop new models capable of better predicting the FDFMC at the study area.

\section{MATERIAL AND METHODS}

All the procedures necessary for the development of this study were carried out in the municipality of Itabaiana (10 $41^{\prime} 06^{\prime \prime S}$ e $37^{\circ} 25^{\prime} 30^{\prime}$ 'O), located in the state of Sergipe, Northeast region of Brazil. The climate, according to the updated classification of Köppen and Geiger, is Equatorial savannah with dry summer (As) (KOTTEK et al. 2006), with an average annual rainfall of $782 \mathrm{~mm}$. November is the driest month with an average of $38 \mathrm{~mm}$ of rainfall and June is the month with the highest average rainfall $(98 \mathrm{~mm})$. The average temperatures vary during the year by $4.1^{\circ} \mathrm{C}$, with an average annual of $24.4^{\circ} \mathrm{C}$ (CLIMATE-DATA, 2021).

The fine dead fuel load was collected in open areas. Some of them dominated by grasses (Poaceae) and others with spaced tree vegetation. No samples were collected of closed canopy forest litter. Therefore, the fuel load was composed mainly from cured grasses and dead leaves. In the area where the fuel was collected, a DAVIS Vantage Vue weather station (K6250 model) was installed at 1.8 meters high and programed to measure the meteorological variables every 10 minutes.

Initially, the fine fuel load was collected from each random $0,0625 \mathrm{~m}^{2}$ parcel. The fuel was then packed in paper bags and immediately had their fresh mass determined with a scale with precision of $0.1 \mathrm{~g}$. In total, 861

FLORESTA, Curitiba, PR, v. 51, n. 3, p. 696-702, jul/set 2021. 
samples were weighed, each had a wet fuel load between 50 and $100 \mathrm{~g}$. The sampling procedure was done over two year period on random days and different day and night hours. After the fuel samples had their fresh mass determined, they were taken to a laboratory and dried in an oven at $100^{\circ} \mathrm{C}$ until they reached constant weight (approximately 24h) then had their dry mass and moisture content determined. The fuel moisture content was correlated with meteorological parameters measured by the weather station at the time when the fuel samples were collected. The meteorological parameters measured in this study were: air temperature, air relative humidity, wind speed, rainfall in the last 24 hours and days since the last rainfall. The nominal dependent variable (fine dead fuel moisture content) was modeled using the forward stepwise procedure to select which of the weather parameters better explained its variation.

The FDFMC estimated by the FWI - FFMC was determined for each sample using the FWI Calculator version 10.4.1.107. It was necessary to convert the FFMC into the FDFMC using the following equation (Equation $1)$.

$F D F M C=101-F F M C$

(Equation 1)

Where: $F D F M C=$ fine dead fuel moisture content; $F F M C=$ Fine fuel moisture code from the FWI index.

The efficiency of the FWI - FFMC was evaluated through the analysis of variance (ANOVA) between real and estimated values. The efficiency of the regression models developed in this study were assessed through the coefficient of determination $\left(\mathrm{r}^{2}\right)$, the p-value coefficient and the root mean square error (RMSE). All statistical analysis were performed using the software JMP version 7.0. The significance level was set at $\alpha=0.05 \%$.

\section{RESULTS}

Based on the analysis of the 861 samples, the real FDFMC ranged from $1.8 \%$ to $75.2 \%$ with a mean value of $17.5 \%$. The FDFMC estimated by the FWI - FFMC ranged from $6,6 \%$ to $96,1 \%$, presenting a mean value of $25,5 \%$. The variation of the real and estimated FDFMC and of the meteorological parameters registered during the sampling procedures are shown below (Table 2).

Table 2. List of minimum, maximum and mean values of all variables used in this study.

Tabela 2. Lista dos valores médios, mínimos e máximos de todas as variáveis utilizadas neste estudo.

\begin{tabular}{lcccc}
\hline \multicolumn{1}{c}{ Parameter } & Minimum & Maximum & Mean & $\begin{array}{c}\text { Standard } \\
\text { Deviation }\end{array}$ \\
\hline Real FDFMC $(\%)$ & 1.8 & 75.2 & 17.5 & 13.1 \\
Estimated FDFMC (FWI - FFMC) $(\%)$ & 6,6 & 96,1 & 25,5 & 17.9 \\
Air Temperature ( $\left.{ }^{\circ} \mathrm{C}\right)$ & 20.3 & 38.7 & 27.5 & 3.2 \\
Air Humidity $(\%)$ & 25.8 & 99 & 71.4 & 13.3 \\
Rainfall in the last 24 hours (mm) & 0 & 75 & 2.3 & 8.1 \\
Wind Speed $\left(\mathrm{km} \mathrm{h}^{-1}\right)$ & 0 & 24.5 & 2.8 & 5.2 \\
Days without rainfall (day) & 0 & 33 & 4 & 6.3 \\
\hline
\end{tabular}

The FWI - FFMC overestimated the real FDFMC in most cases. Its average value was $8 \%$ higher than the measured FDFMC. According ANOVA test, the estimated values was statistically different from the real $(\mathrm{F}=$ 102.53; $p<0.001)$. Since both variables presented a significant correlation $(r=0.79 ; p<0.001)$, it was possible to build an adjustment model (Equation 2) using linear regression $\left(r^{2}=0.63 ; p<0.001 ;\right.$ RMSE $\left.=7.85\right)($ Figure 1$)$.

$F D F M C_{\text {real }}=2.67+0.57 * F D F M C_{\text {estimated }}$

(Equation 2)

Where: $F D F M C_{\text {real }}$ - Measured fine dead fuel moisture content; $F D F M C_{\text {estimatade }}-$ Estimated fine dead fuel moisture content using the FWI - FFMC.

FLORESTA, Curitiba, PR, v. 51, n. 3, p. 696-702, jul/set 2021 

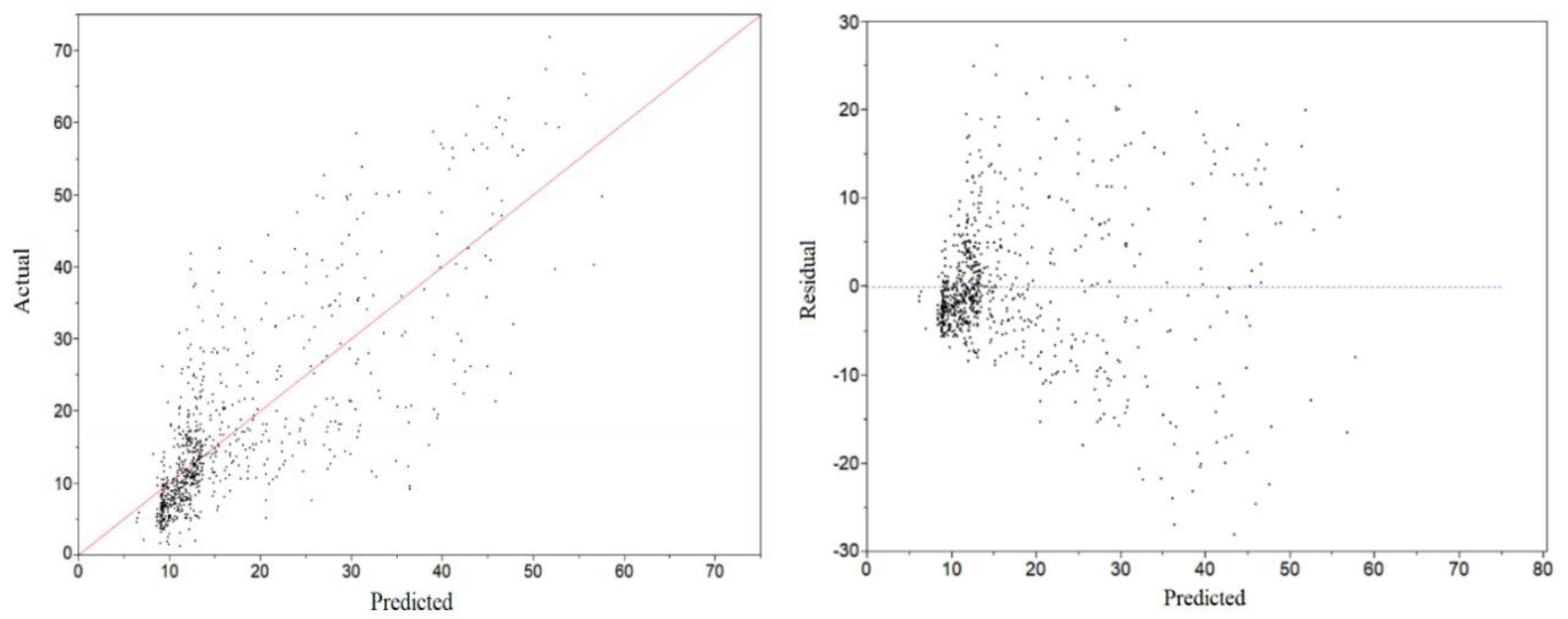

Figure 1. FDFMC observed (actual) versus predicted by using the FWI - FFMC (plot on the left side). On the right, plot of residuals versus predicted response.

Figura 1. TUMMF observado (actual) versus previsto (predicted) utilizando o FFMC do FWI (gráfico à esquerda). Na direita, gráfico da distribuição dos resíduos.

Seeking to better predict the FDFMC at the study site, a new multivariate regression model was created. Using the forward stepwise procedure, air relative humidity was the most significant variable responsible for the variation of the FDFMC ( $p<0.001)$, followed by the rainfall amount in the last 24 hours $(\mathrm{p}<0.001)$ and by the number of days without rainfall $(p<0.001)$. The inclusion of the variables air temperature $(p=0.09)$ and windspeed $(\mathrm{p}=0.12)$ did not result in a significant improvement of the model efficiency, therefore, both were disregarded. The best fitted model was obtained through nonlinear regression $\left(\mathrm{r}^{2}=0.76 ; \mathrm{p}<0.001\right.$; RMSE $\left.=6.8\right)$ (Equation 3). The proposed model presented a better coefficient of determination and lower error than the FWI FFMC adjustment model (Figure 2). As the data used to create the proposed model was measured during the 24 hours of the day, the model can be used at any time.

$F D F M C=e^{1.54319+0.00022 * H^{2}+0.13659 * \sqrt{R_{24 h}}-0.13032 * N D W R}$

(Equation 3)

Where: FDFMC - Fine dead fuel moisture content (\%); $e$ - Base of the natural logarithm $=2.71828 ; H$ - Air relative humidity (\%); $R_{24 h}$ - Rainfall amount in the last 24 hours (mm); NDWR - Number of days without rainfall.
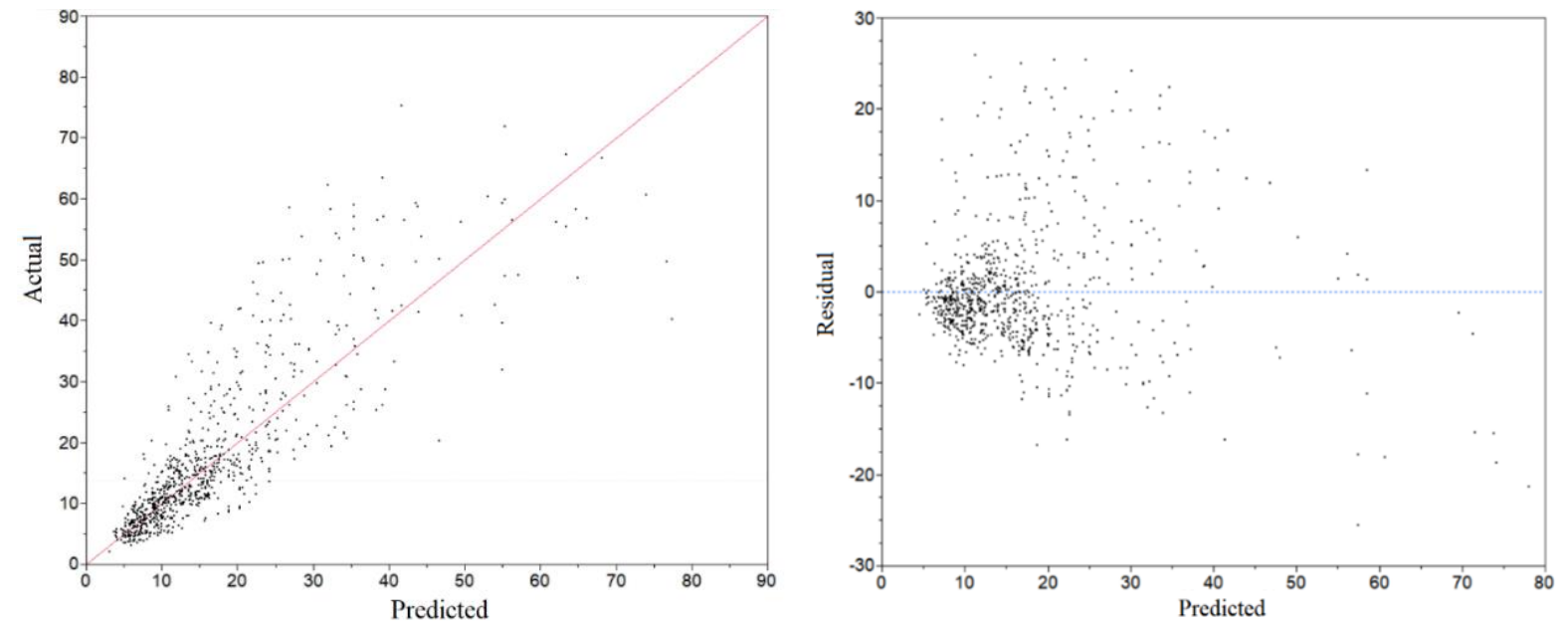

Figure 2. FDFMC observed (actual) versus predicted using the proposed model (on the left side). On the right, plot of residuals versus predicted response.

Figura 2. TUMMF observado (actual) versus previsto (predicted) utilizando o modelo proposto (gráfico à esquerda). Na direita, gráfico da distribuição dos resíduos. 


\section{DISCUSSION}

The FWI is a set of mathematical equations that is used as a fire danger rating system based on dozens of experimental works, conducted between 1928 and 1970, in Canadian natural pine forests (VAN WAGNER, 1974). It is the most tested and used model in the world and usually presents good results. The FWI had its efficiency proven in different countries, such as Argentina (BIANCHI; DEFOSSE, 2014); Australia (DOWDY et al., 2010); China (LI et al., 2014; ZHANG et al., 2014); Canada (WADDINGTON et al., 2011); Portugal (FERNANDES et al., 2010); Spain (GABBAN et al., 2008); Greece (KARALI et al., 2013); Germany (HOLSTEN et al. 2013); United States (ROADS et al., 2010).

However, publications that report inaccuracy of the FWI index are also common. In a study in Slovenia, for example, Sturm et al. (2012) concluded that the results obtained with the original FWI were not satisfactory; Simpson et al. (2014) found that a FWI hazard class calibration was required in New Zealand for the effective use of the model. Jong et al. (2016) concluded that a calibration of the FWI was necessary in order to avoid large errors with respect to the identification of periods of significantly elevated fire danger in the United Kingdom. Dimitrakopoulos et al. (2011) proposed a new classification of the FWI because the existing fire danger classes were found unsuitable for the dry and extremely fire prone eastern Mediterranean climate.

In two Brazilian studies using average daily data (TORRES et al., 2017; TORRES; LIMA, 2019), it was concluded that the FWI was not efficient in predicting forest fires in the areas where the experiments were carried out.

The results found in this work showed that the FWI - FFMC overestimated the real FDFMC by approximately $8 \%$. However, both variables presented a high and significant correlation, which provided the design of an adjustment model. The differences between actual and estimated values can be justified by differences in vegetation and climate aspects. The areas where the experiments to develop the FWI were done present temperate climate with predominance of pine forests. The areas used in this study present equatorial climate with vegetation ranging from tropical forests to open areas dominated by grasses. This conclusion is based on the fact that the physical process of fuel moisture absorption or desorption depend on fuel characteristics such as surface area to volume ratio and weather conditions (NELSON, 1984). Also, empirical models such as the FWI that are built based on experimental observations, generally have their use restricted to areas with similar characteristics from where the experiments were conducted (WHITE, 2018). It is always recommended to evaluate the efficiency of fire risk or fire behavior models before using them operationally in a certain region, especially if the climate and vegetation characteristics are different from which the models were developed (WHITE et al., 2016).

Despite the existence of dozens of mathematical models built to estimate the fuel moisture content of dead fuels (MATTHEWS, 2014), only one model was found in the literature that was developed using empirical data of FMC measured in a Brazilian equatorial climate region (RAY et al., 2010). Nevertheless, the model in question was built to estimate the FMC of the Amazon rainforest litter. In addition to using the number of days without rainfall, the air temperature and relative humidity (in the form of the vapor pressure deficit), the respective model uses the foliar area index of the forest as an input variable. Therefore, its use for areas without tree cover is impractical.

The new model has as input three variables (air humidity, rainfall amount and days without rainfall) that have already been proved to have a substantial effect on the fine dead fuel moisture content (VAN WAGNER, 1974; RAY et al., 2010; WHITE et al., 2016). Despite several authors consider that the processes involving rainfall are too complex for modelling the FMC (MATTHEWS et al., 2010), the new model presented good statistical parameters. It differs from other models that are commonly used to determine the fire danger and/or the FMC, for being capable to be utilized at any hour of the day and for its simplicity. Any person that has access to a weather station with a pluviometer and a hygrometer can use the model.

\section{CONCLUSION}

- Comparing the measured data of the fine dead fuel moisture content with the value predicted by the FWI Fine Fuel Moisture Code (FFMC), it was observed a significant statistical difference between both. The FFMC average value was $8 \%$ higher than the measured mean fuel moisture content. Therefore, due the possibility of the FFMC underestimate the fire risk, its use is not recommended for the study area.

- Air relative humidity was the most significant variable responsible for the variation of the FDFMC, followed by the rainfall amount in the last 24 hours and by the number of days without rainfall.

- The proposed model presented better statistical parameters and has the advantage of using easily measured meteorological variables that can be determined at any hour of the day.

- New studies should be done in different equatorial climate regions to evaluate the efficiency of the proposed model. If its efficiency is proven, the model can be used as a fire risk index, since the FDFMC is directly

FLORESTA, Curitiba, PR, v. 51, n. 3, p. 696-702, jul/set 2021

White, B. L. A. et.al.

ISSN eletrônico 1982-4688

DOI: $10.5380 /$ rf.v51 i3. 72389 
related to the fuel ignition and fire behavior. Also, it can be used as a tool for determining the ideal conditions to perform prescribed/control burns.

\section{ACKNOWLEDGEMENTS}

To the Conselho Nacional de Desenvolvimento Científico e Tecnológico (CNPq) and to the Fundação de Apoio à Pesquisa e a Inovação Tecnológica do Estado de Sergipe (FAPITEC) for funding this study.

\section{REFERENCES}

BIANCHI, L. O.; DEFOSSE, G. E. Ignition probability of fine dead surface fuels of native Patagonian forests or Argentina. Forest Systems, Madrid, v. 23, p. 129-138, 2014.

CLIMATE-DATA. Itabaiana Climate. Available at: <https://pt.climate-data.org/america-dosul/brasil/sergipe/itabaiana-42970/> Accessed in: 04/29/2021.

DIMITRAKOPOULOS, A. P.; BEMMERZOUK, A. M.; MITSOPOULOS, I. D. Evaluation of the Canadian fire weather index system in an eastern Mediterranean environment. Meteorological Applications, [S.1.], v. 18, n. 1, p. 83-93, 2011.

DOWDY, A. J.; MILLS, G. A.; FINKELE, K.; DE GROOT, W. Index sensitivity analysis applied to the Canadian forest fire weather index and the McArthur forest fire danger index. Meteorological Applications, [S.1.], v. 17, n. 3, p. 298-312, 2010.

FERNANDES, P. M.; LUZ, A.; LOUREIRO, C. Changes in wildfire severity from maritime pine woodland to contiguous forest types in the mountains of northwestern Portugal. Forest Ecology and Management, Amsterdam, v. 260, n. 5, p. 883-892, 2010.

GABBAN A.; AYANZ, J. S. M.; VIEGAS, D. X. A comparative analysis of the use of NOAA-AVHRR NDVI and FWI data for forest fire risk assessment. International Journal of Remote Sensing, [S.1.], v. 29, n. 19, p. 5677-5687, 2008.

GISBORNE, H. T. Measuring forest-fire danger in northern Idaho. Washington: US Department of Agriculture, 1928. 63 p. (Miscellaneous publication no. 29).

JONG, M. C. DE; WOOSTER, M. J.; KITCHEN, K.; MANLEY, C.; GAZZARD, R.; MCCALL, F. F. Calibration and evaluation of the Canadian Forest Fire Weather Index (FWI) System for improved wildland fire danger rating in the United Kingdom. Natural Hazards in Earth System Sciences, Munich, v. 16, n. 5, p. 1217-1237, 2016.

HOLSTEN, A.; DOMINIC, A. R.; COSTA, L.; KROPP, J. P. Evaluation of the performance of meteorological forest fire indices for German federal states. Forest Ecology and Management, Amsterdam, v. 287, p. 123-131, 2013.

KARALI, A.; ROUSSOS, A.; GIANNAKOPOULOS, C.; HATZAKI, M.; XANTHOPOULOS, G.; KAOUKIS, K. Evaluation of the Canadian Fire Weather Index in Greece and future climate projections. In: HELMIS, C. G.; NASTOS, P. T. (Eds.). Advances in Meteorology, Climatology and Atmospheric Physics. Berlim: Springer, 2013. p. 501-508.

KOTTEK, M.; GRIESER, J.; BECK, C.; RUDOLF, B.; RUBEL, F. World map of the Köppen-Geiger climate classification updated. Meteorologische Zeitschrift, Berlin, v. 15, n. 3, p. 259-263, 2006.

LI, X.; ZHAO, G.; YU, X.; YU, Q. A comparison of forest fire indices for predicting fire risk in contrasting climates in China. Natural Hazards, [S.1.], v. 70, n. 2, 1339-1356, 2014.

MATTHEWS, S. Dead fuel moisture research: 1991-2012. International Journal of Wildland Fire, Clayton, v. 23, n. 1, p. 78-92, 2014.

MATTHEWS, S.; GOULD, J.; MCCAW, L. Simple models for predicting dead fuel moisture in eucalyptus forests. International Journal of Wildland Fire, Clayton, v. 19, n. 4, p. 459-467, 2010.

NELSON, R. M. A. A method for describing equilibrium moisture content of forest fuels. Canadian Journal of Forest Research, Birmingham, v. 14, n. 4, p. 597-600, 1984.

RAY, D.; NEPSTAD, D.; BRANDO, P. Predicting moisture dynamics of fine understory fuels in a moist tropical rainforest system: results of a pilot study undertaken to identify proxy variables useful for rating fire danger. New Phytologist, Cambridge v. 187, n. 3, p. 720-732, 2010. 
ROADS, J.; TRIPP, P.; JUANG, H.; WANG, J.; FUJIOKA, F.; CHEN, S. NCEP-ECPC monthly to seasonal US fire danger forecasts. International Journal of Wildland Fire, Clayton, v. 19, n. 4, p. 399-414, 2010.

SIMPSON, C. C.; PEARCE, H. G.; STURMAN, A. P.; ZAWAR-REZA, P. Behaviour of fire weather indices in the 2009-10 New Zealand wildland fire season. International Journal of Wildland Fire, Clayton, v. 23, n. 8, p. 1147-1164, 2014.

STURM, T.; FERNANDES, P. M.; SUMRADA, R. The Canadian fire weather index system and wildfire activity in the Karst forest management area, Slovenia. European Journal of Forest Research, Novi Sad, v. 131, n. 3, p. 829-834, 2012.

TORRES, F. T. P.; LIMA, G. S. Forest Fire Hazard in the Serra do Brigadeiro State Park (MG). Floresta e Ambiente, Seropédica, v. 26, n. 2, p. 1 - 9, 2019.

TORRES, F. T. P.; LIMA, G. S.; MARTINS, S. V.; VALVERDE, S. R. Analysis of efficiency of fire danger indices in forest fire prediction. Revista árvore, Viçosa, v. 41, n. 2, e410209, 2017.

VAN WAGNER, C. E. Structure of the Canadian forest fire weather index. Ottawa, ON: Canadian Forestry Service, Petawawa Forest Experiment Station, Department of the Environment, 1974. (Publication No. 1333).

WHITE, B. L. A. Modelos matemáticos de previsão do teor de umidade dos materiais combustíveis florestais finos e mortos. Ciência Florestal, Santa Maria, v. 28, n. 1, p. 432-445, 2018.

WHITE, B. L. A.; WHITE, L. A. S.; RIBEIRO, G. T.; SOUZA, R. M. Fire behavior predicting models efficiency in Brazilian commercial eucalypt plantations. Cerne, Lavras, v. 22, n. 4, p. 389-396, 2016.

ZHANG, H.; JIN, S.; DI, X. Y. Prediction of litter moisture content in Tahe Forestry Bureau of Northeast China based on FWI moisture codes. The Journal of Applied Ecology, London, v. 25, n. 7, p. 2049-2055, 2014. 